\title{
Nominal and Real Effective Exchange Rates for Bangladesh: 1973:07-2008:12
}

\author{
${ }^{1}$ Gour Gobinda Goswami*, 2Mohammad Monirul Islam Sarker \\ ${ }^{1}$ Department of Economics, North South University, Dhaka 1229, Bangladesh \\ 2Monetary Policy Department, Bangladesh Bank, Head Office, Dhaka 1000 \\ *gour@northsouth.edu
}

\begin{abstract}
Bilateral real exchange rate is used in examining the price of domestic goods in terms of partner's goods and it is especially useful for bilateral modelling. On the other hand, real effective exchange rate serves as the price of domestic goods in terms of a basket of foreign goods and is especially useful for aggregate or multilateral modelling.The method of construction of both the bilateral and the multilateral or effective exchange rate depends on the definition of nominal bilateral exchange rate (direct or indirect), the method of averaging (arithmetic or geometric), and the calculation of trade weight (considering either the value of export or import or total trade). This paper uses both the arithmetic and the geometric mean as averaging technique and considers three kinds of trade weights, namely, export weights, import weights, and total trade weights in the construction of effective exchange rate indices. Using twenty one major trading partners of Bangladesh, which covers about 80 percent of her total trade, we prepare a comprehensive data base on nominal effective exchange rates, real effective exchange rates, trade policy bias index etc. both by using the fixed and the variable weight for the period 1973:072008:12 on a monthly basis. From this study it has been observed that there is a declining trend in the effective exchange rates of Bangladesh, which indicates an overall devaluation of Bangladeshi taka against her partner currencies both bilaterally and multilaterally. The result is robust no matter whether we use the fixed or the variable weight. As a supplementary exercise, the prepared data has been used in estimating the trade policy bias index and it is found that Bangladesh's trade policy has become proexport starting from December 2000. However, the process has been slowed down slightly in the most recent time.
\end{abstract}

Key Words: Effective Exchange Rates, Nominal Effective Exchange Rates, Real Effective Exchange Rates, Bilateral Exchange Rates, Multilateral Exchange Rates.

\section{Introduction}

The concept of nominal and real exchange rate is extremely useful in the context of open economy macroeconomics in the sense that exchange rate measures competitiveness of our product in the international market as well as debt servicing liability of a country. Both the bilateral and the multilateral exchange rate can be expressed in nominal and real terms. The nominal effective exchange rate (henceforth NEER) expresses the price of the domestic currency relative to the currencies of its major trading partners while the real effective exchange rate (henceforth REER) provides an indication of changes in competitive position between countries. There are three key elements in the calculation of the effective exchange rate (henceforth EER) index: the number of bilateral exchange rates included, i.e., currency basket, their weights, and price indices used. The methodology (arithmetic or geometric mean method) and weights used to calculate the effective exchange rate indices have a great effect on their values. Usually the major trading partners as well as currency basket are selected depending on the value of exports or imports or total trade (exports plus imports) of the domestic country with each trading partner. The weights are measured by calculating the proportion of home country's trade with each trading partner to total trading partners. The trade weights used in calculating the effective exchange rate may either be fixed or variable. Usually, the fixed trade weights are calculated by using the value of exports and imports in the base period. But the variable trade weights are calculated by revising the trade weight in each time period. Price indices used for constructing the real effective exchange rate may be represented either by consumer price index (CPI) or producer price index (PPI) or GDP deflator.

Bangladesh Bank (BB) constructs the effective exchange rate index to measure the competitiveness of taka against trading partners' currencies. BB started to construct the real effective exchange rate index from January 1986 and uses it to calculate depreciation or appreciation of taka with major trading partners' currencies. Before 1986 bilateral exchange rate was used for calculating the depreciation or appreciation of Bangladesh taka under the adjustment process. At the initial stage, BB considered only six currencies, namely, the currencies of Germany, Japan, United Kingdom, India, Pakistan, and United States 
as major trading partners' currencies to calculate nominal effective exchange rate and REER indices. The number of partner countries was gradually increased to fifteen by December 2001. From January 2002, when twelve member states of the European Union introduced euro as a single currency of the union, the major trading partners of Bangladesh was reduced to eleven and the Fiscal Year 1994-95 (henceforth FY95) was used as base year to calculate the effective exchange rate indices. Recently (from January 2008), BB has been using only eight currencies as currency basket and FY01 as base year to calculate the NEER and REER indices of Bangladesh. The previous base periods used by BB were: 1983, 1988, 1992, and 1993-94. BB has been calculating the NEER and REER indices on daily and monthly basis respectively. But there are some drawbacks in the construction procedure. BB has been using only eight currency areas as trading partner of Bangladesh which covers only $60 \%$ of her total trade. There is no study that uses the variable trade weights to calculate the effective exchange rate indices of Bangladesh. Hence, it is quite difficult to examine whether there exists any structural change in the purchasing power of our currency vis-à-vis other trading partners' currencies. Besides, there is no study that uses both the arithmetic and the geometric mean as the averaging techniques. Few other studies attempt to construct the effective exchange rate index for developing countries excluding Bangladesh (Bahmani-Oskooee, 1995; Bahmani-Oskooee and Mirzai, 2000; Bahmani-Oskooee and Gelan, 2007; Bahmani-Oskooee and Harvey, 2007; Bahmani-Oskooee and Kandil, 2007). Few other studies mostly construct the effective exchange rate as part of other projects and a comprehensive study with latest data and upgraded base period is urgently needed in the context of Bangladesh in the wake of its growing importance in international trade and finance. ${ }^{1}$

Considering this situation, this paper attempts to construct the effective exchange rate of Bangladesh for more than thirty five years on monthly basis (from July 1973 to December 2008) taking FY01 as the base period both in the framework of fixed and variable weight. In this way, this paper attempts to cover most of the important aspects in constructing the effective exchange rate index. It is to be noted that IMF in its International Financial Statistics publishes the data for effective exchange rates only for developed countries not for developing countries. Bahmani-Oskooee (1995), Bahmani-Oskooee and Mirzai (2000), Bahmani-Oskooee and Gelan (2007), Bahmani-Oskooee and Kandil (2007), and Bahmani-Oskooee and Harvey (2007) make attempts to calculate the effective exchange rates for developing countries. They did it for many developing countries but their list does not include Bangladesh. Researchers in the field of International Finance face problem in finding an authentic data base for effective exchange rates of Bangladesh. Most of the time researchers who work with aggregate approach in modeling export, import, or trade balance have to prepare a separate data base for effective exchange rates which captures bulk of their time and leave only limited amount of time available for modeling. Hence, it is a growing demand from the academia for conducting such a study that can provide a high frequency data for nominal and real effective exchange rates readily available for Bangladesh. To this end, this paper is divided into six sections. The literature review is provided in section two. Section three presents different steps for the construction of effective exchange rate. The data set of effective exchange rates are constructed and provided in section four. Section five provides detailed analysis in the context of competitiveness and trade policy bias. Section six presents the summary and concluding remarks.

\section{Literature Review}

As mentioned earlier, IMF regularly publishes the data of both the nominal and the real effective exchange rates for developed countries to monitor their competitiveness in international trade. To supplement IMF data there exist a limited number of studies regarding the construction of effective exchange rates for developing countries, but no particular study is available regarding Bangladesh except Rahman (1992). In this connection, Bahmani-Oskooee (1995) constructs both the nominal and the real effective exchange rates for twenty two developing countries over the period 1971-1990 on quarterly basis. BahmaniOskooee and Mirzai (2000) construct both the nominal and the real effective exchange rates for twenty developing countries over the period of 1973-1997 on quarterly basis. They use the value of total trade (exports plus imports) to calculate the trade weight and arithmetic mean to calculate the weighted average.

Bahmani-Oskooee (2001) constructs both the real and nominal effective exchange rates for eleven Middle Eastern countries over 1971I-1994IV period. He also investigates the long-run response of the trade

\footnotetext{
${ }^{1}$ Bahmani-Oskooee and Goswami (2003) construct real effective exchange rate for Japan in examining the JCurve phenomenon.
} 
balances of these countries to devaluation. Recently, Bahmani-Oskooe \& Gelan (2007) construct the nominal and real effective exchange rates over the 1971I-2004III period for twenty one African countries. They also test the stationarity of the real effective rates and find that the purchasing power parity theory holds only in four out of twenty one cases. Bahmani-Oskooee and Kandil (2007) construct the real and nominal effective exchange rates for fourteen Middle East and North African countries over the 19702004 periods. They test the validity of the Purchasing Power Parity (PPP) by applying the ADF and KPSS tests to the real effective exchange rates. They also employ the bounds testing approach to cointegration and error-correction modeling. In another study, Bahmani-Oskooee \& Harvey (2007) construct the real and nominal effective exchange rates for the least developed countries over the 1971I-2004IV period. Some studies use both the nominal and the real effective exchange rates as part of other projects. ${ }^{2}$ Rahman (1992) constructs four types of effective exchange rate indices, namely, (i) nominal effective exchange rate for exports, (ii) nominal effective exchange rate for imports, (iii) real effective exchange rate for exports, and (iv) real effective exchange rate for imports for the period over FY74-FY89 on yearly basis using the base period FY86. He observes significant depreciating trend in the nominal exchange rate, but the real exchange rate changes very little throughout the 1980s. The nominal depreciation over the prescribed time period worked as a safeguard against overvaluation of our currency with her major trading partners and had a favorable impact on nominal export growth. Though, frequent exchange rate adjustments helped export growth, the trade policy biased against exports. He argues that some factors other than exchange rate depreciation are perhaps more important determinants of the high export growth observed in the post 1984 period in Bangladesh.

It is to be mentioned that none of the studies mentioned above prepare any data base for Bangladesh regarding her nominal and real effective exchange rates for long time on a monthly or quarterly basis or disregards Bangladesh totally. This motivates us to construct a comprehensive as well high frequency data base for the nominal and the real effective exchange rates for Bangladesh. This data base is expected to be used by policy makers, and researchers who want to examine the competitiveness of Bangladesh vis-à-vis her trading partners.

\section{Different Steps for the Construction of Effective Exchange Rates}

To construct the nominal and real effective exchange rates economist follow certain number of steps. The main steps are: selection of trading partners, selection of base period, calculation of trade weights, calculation of bilateral nominal exchange rates and indices, and calculation of bilateral real exchange rates and indices.

Selection of Trading Partners: Selection of major trading partners depends on (i) the value of exports or (ii) the value of imports or (iii) the value of total trade (exports plus imports) of home country with trading partners. In this regard, we observe the value of total trade with different trading partners of Bangladesh for FY96, FY01, and FY06; and select twenty one countries as major trading partners of Bangladesh that capture about 80 percent of her total trade. The countries included are: Belgium, Canada, China, France, Germany, Hong Kong, India, Indonesia, Italy, Japan, South Korea, Kuwait, Malaysia, Netherlands, Pakistan, Singapore, Spain, Sweden, Thailand, UK, and USA.

Selection of Base Year: The value of exchange rate in the base year is used to make the current exchange rate unit free. The value of base year index is equal to 100 by definition. Usually the base year is selected considering normal situation both in social and economic arena. Bangladesh Bureau of Statistics (BBS) uses FY96 as base year for analyzing most of the macroeconomic data say, GDP at constant price, CPI etc. Bangladesh Bank (BB) uses FY01 as base year in constructing the effective exchange rate index. Besides, IMF uses Year 2000 as base year in analyzing all macroeconomic variables including NEER and REER indices for developed countries. Considering this situation, this paper uses FY01 as the base year in calculating the effective exchange rate index.

\section{Results and Discussion}

Calculation of Trade Weight: The trade weights that are used in constructing the effective exchange rate index reflect the relative importance of each foreign currency to the home country. It is common practice to use (i) the value of exports or (ii) the value of imports or (iii) the value of total trade (exports plus

\footnotetext{
${ }^{2}$ Rahman (1992) uses it for Bangladesh, Bahmani-Oskooee and Goswami (2003) use it for Japan.
} 
imports) to calculate the trade weights. This paper uses these three approaches to calculate bilateral trade weights. Whichever weights are used, the actual construction of EER index depends upon the averaging technique (arithmetic or geometric) used and also to the definition of exchange rate (direct or indirect). This paper uses both arithmetic and geometric mean as averaging technique and indirect bilateral exchange rate to construct EER index. In this paper, the higher value of EER index indicates appreciation and the lower value indicates depreciation of taka against partner currencies. But the actual trend of change in exchange rate i.e. appreciation/depreciation does not depend on whether we use direct or indirect exchange rate in constructing the EER indices.

In calculating the trade weight it is considered that there is no country other than selected trading partners which has any economic transaction with Bangladesh. That means that the sum of all trade weights with major trading partners is equal to one. There are two types of trade weights, namely, the fixed trade weight and the variable trade weight. If we use value of exports, value of imports, and value of total trade separately, we get three kinds of 'fixed trade weight' which may be calculated by using the following formula:

$$
W^{i X}=\frac{X_{b}^{i}}{X_{b}}, W^{i M}=\frac{M_{b}^{i}}{M_{b}}, \text { and } W^{i T}=\frac{X_{b}^{i}+M_{b}^{i}}{X_{b}+M_{b}}
$$

where, $W^{i x}=$ fixed export weight of Bangladesh with its partner i;

$W^{\text {im }}=$ fixed import weight of Bangladesh with its partner $\mathrm{i}$;

$W^{i t}=$ fixed trade weight of Bangladesh with its partner i;

$X_{b}^{i}=$ value of exports of Bangladesh to partner i at base period;

$M_{b}^{i}=$ value of imports of Bangladesh from partner i at base period;

$X_{b}=$ value of exports of Bangladesh to all trading partners at base period;

$M_{b}=$ value of imports of Bangladesh from all trading partners at base period.

Note that, $\sum_{i=1}^{21} W^{i X}=\sum_{i=1}^{21} W^{i M}=\sum_{i=1}^{21} W^{i T}=1^{\prime} \sum_{i=1}^{21} X_{b}^{i}=X_{b}{ }^{\prime}$ and $\sum_{i=1}^{21} M_{b}^{i}=M_{b}$. Using these formulae, three kinds of fixed trade weights are calculated for Bangladesh for FY01.

Table 1: Partner-wise Fixed Trade Weights of Bangladesh for FY01

\begin{tabular}{l|c|c|c}
\hline Partner Country & For Exports & For Imports & For Total Trade \\
\cline { 2 - 4 } & 1 & 2 & 3 \\
\hline Belgium & 4.09 & 0.43 & 1.98 \\
Canada & 2.18 & 1.55 & 1.82 \\
China & 0.17 & 11.24 & 6.56 \\
France & 6.50 & 1.08 & 3.37 \\
Germany & 14.01 & 3.27 & 7.81 \\
Hong Kong & 2.19 & 7.57 & 5.30 \\
India & 1.23 & 18.77 & 11.36 \\
Indonesia & 0.11 & 3.00 & 1.78 \\
Italy & 5.81 & 1.70 & 3.43 \\
Japan & 1.56 & 13.41 & 8.40 \\
Korea (South) & 0.13 & 6.52 & 3.82 \\
Kuwait & 0.05 & 0.64 & 0.39 \\
Malaysia & 0.13 & 2.34 & 1.41 \\
Netherlands & 5.61 & 1.30 & 3.12 \\
Pakistan & 0.74 & 1.51 & 1.19 \\
Singapore & 0.66 & 13.06 & 7.82 \\
Spain & 1.77 & 0.39 & 0.98 \\
Sweden & 1.92 & 0.79 & 1.27 \\
Thailand & 0.48 & 3.17 & 2.03 \\
UK & 10.45 & 4.32 & 6.91 \\
USA & 40.19 & 3.93 & 19.26 \\
Total & 100.00 & 100.00 & 100.00 \\
\hline Sori Autors
\end{tabular}

Source: Authors' own calculation based on 'Annual Exports Receipts 2007/08' and 'Annual Imports Payments 2007/08' of BB. 
Table 1 depicts that USA, Germany, and UK are the $1^{\text {st }}, 2^{\text {nd }}$ and the $3^{\text {rd }}$ largest and Indonesia is the smallest importers of Bangladeshi commodity among twenty one major trading partners of Bangladesh. With respect to imports India, Japan, Singapore, and China bear two-digit imports share of Bangladesh. Among the twenty one major trading partners Spain, Belgium, Kuwait, and Sweden capture less than one percent of import share. According to the total trade share, USA and India are the $1^{\text {st }}$ and the $2^{\text {nd }}$ largest and Kuwait is the smallest trading partner of Bangladesh. It may be mentioned that, in case of India, only the officially recorded transactions are considered in calculating the trade weight, but there may be unrecorded trade with India because of our proximity. Therefore, the actual trade weights with India may be higher than 11.36 percent stated in the table. Now the formulae for calculating the variable trade weights are given below:

$$
W_{t}^{i X}=\frac{X_{t}^{i} X_{t}^{\prime}}{X_{t}^{i M}}=\frac{M_{t}^{i}}{M_{t}} W_{t}^{i T}=\frac{X_{t}^{i}+M_{t}^{i}}{X_{t}+M_{t}}
$$

where, $W_{t}^{i x}=$ variable export weight of Bangladesh with its partner i at period t;

$W_{t}^{i M}=$ variable import weight of Bangladesh with its partner i at period $\mathrm{t}$;

$W_{t}^{i T}=$ variable trade weight of Bangladesh with its partner i at period t;

$X_{t}^{i}=$ value of exports of Bangladesh to partner $\mathrm{i}$ at period $\mathrm{t}$;

$M_{t}^{i}=$ value of imports of Bangladesh from partner i at period $\mathrm{t}$;

$X_{i}=$ value of exports of Bangladesh to all partners at period t;

$M_{t}=$ value of imports of Bangladesh from all partners at period t;

By definition, $\sum_{i=1}^{21} W_{t}^{i X}=\sum_{i=1}^{21} W_{t}^{i M}=\sum_{i=1}^{21} W_{t}^{i T}=1^{\prime} \sum_{i=1}^{21} X_{t}^{i}=X_{t}{ }^{\prime}$ and $\sum_{i=1}^{21} M_{t}^{i}=M_{t}$. Using the formulae of variable trade

weights, three kinds of trade weights of Bangladesh are calculated on monthly basis over the period 1973:07-2008:12 for constructing the NEER and REER indices. It is observed that there is a structural change in the trend of variable trade weights with different partner countries. Table 2 shows the overall position of partner countries regarding variable trade shares.

Table 2: Partner-wise Variable Trade Weights for FY73 and FY08

\begin{tabular}{l|c|c|c|c|c|c}
\hline \multirow{2}{*}{ Partner } & \multicolumn{2}{|c|}{ For Exports } & \multicolumn{2}{c|}{ For Imports } & \multicolumn{2}{c}{ For Total Trade } \\
\cline { 2 - 7 } & FY74 & FY08 & FY74 & FY08 & FY74 & FY08 \\
\cline { 2 - 7 } & 1 & 2 & 3 & 4 & 5 & 6 \\
\hline Belgium & 6.24 & 4.62 & 1.21 & 0.44 & 2.25 & 1.97 \\
Canada & 2.71 & 4.00 & 12.64 & 2.18 & 10.59 & 2.85 \\
China & 4.43 & 0.94 & 0.23 & 18.74 & 1.10 & 12.21 \\
France & 3.62 & 8.32 & 1.78 & 0.71 & 2.16 & 3.50 \\
Germany & 2.60 & 18.33 & 11.56 & 2.45 & 9.71 & 8.28 \\
Hong Kong & 0.44 & 1.58 & 2.70 & 4.96 & 2.23 & 3.72 \\
India & 10.15 & 2.93 & 10.02 & 20.39 & 10.04 & 13.98 \\
Indonesia & 0.34 & 0.21 & 1.61 & 2.68 & 1.35 & 1.77 \\
Italy & 4.66 & 4.98 & 1.07 & 1.39 & 1.81 & 2.71 \\
Japan & 7.76 & 0.80 & 7.81 & 5.00 & 7.80 & 3.46 \\
Korea & 0.09 & 0.40 & 0.67 & 3.76 & 0.55 & 2.53 \\
Kuwait & 0.36 & 0.07 & 4.21 & 6.92 & 3.41 & 4.40 \\
Malaysia & 0.22 & 0.22 & 0.54 & 2.73 & 0.47 & 1.80 \\
Netherlands & 2.14 & 5.06 & 2.00 & 0.97 & 2.03 & 2.47 \\
Pakistan & 2.60 & 0.70 & 5.71 & 1.44 & 5.06 & 1.17 \\
Singapore & 2.30 & 0.48 & 0.98 & 8.11 & 1.26 & 5.31 \\
Spain & 1.33 & 4.92 & 2.11 & 8.11 & 1.95 & 6.94 \\
Sweden & 0.27 & 2.11 & 1.17 & 1.17 & 0.98 & 1.52 \\
Thailand & 0.25 & 0.07 & 0.27 & 3.02 & 0.26 & 1.94 \\
UK & 15.70 & 11.36 & 4.17 & 1.92 & 6.56 & 5.38 \\
USA & 31.78 & 27.92 & 27.54 & 2.89 & 28.42 & 12.08 \\
Total & 100.00 & 100.00 & 100.00 & 100.00 & 100.00 & 100.00 \\
\hline
\end{tabular}

Source: Authors' own calculation.

From Table 2 it is observed that USA, UK, and India were the $1^{\text {st }}, 2^{\text {nd }}$ and the $3^{\text {rd }}$ largest exporting partners of Bangladesh in FY73. But in FY08 India is no longer the largest export partner of Bangladesh. The export 
share of India declines from 10.15 to 2.93 percent. Besides the export shares of USA and UK also decline from 31.78 to 27.92 and 15.70 to 11.36 per cent respectively. The substantial increase in the export share of other European countries, namely, Germany, France, Spain, and Netherlands offset such declines. On the other hand, where USA, Canada, and Germany were the $1^{\text {st }}, 2^{\text {nd }}$, and the $3^{\text {rd }}$ largest import country of Bangladesh in FY74, these positions are occupied by India, China, and Singapore in FY08. It is remarkable that the import share of China was 0.23 percent in FY74 and stood at 18.45 percent in FY08. Considering total trade weights, it is observed that USA, Canada, and India were the $1^{\text {st }}, 2^{\text {nd }}$ and the $3^{\text {rd }}$ largest and Thailand was the smallest trading partner of Bangladesh in FY74. But in FY08, India, China, and USA are the $1^{\text {st }}, 2^{\text {nd }}$, and the $3^{\text {rd }}$ largest and Pakistan is the smallest trading partners of Bangladesh. Hence, China has emerged as a major trading partner of Bangladesh in recent days which can be considered as a structural shift in our trading pattern with partners.

Calculation of Bilateral Nominal Exchange Rate: The bilateral nominal exchange rates of taka against the currencies of twenty one major trading partners of Bangladesh are calculated by using the following cross formula.

$$
N E R_{t}^{i}=\frac{N E R_{t}^{i \$}}{N E R_{t}^{\S}} \cdots(3)
$$

where, $N E R_{t}^{i}=$ units of country i's currency per unit of taka at period t;

$N E R_{t}^{i s}=$ units of country i's currency per unit of US\$ at period t;

$N E R_{t}^{\mathrm{s}}=$ units of taka per unit of US\$ at period t;

We know that out of twenty one major trading partners Belgium, Germany, France, Italy, Netherlands, and Spain are the members of euro area. In January 1, 2002, the twelve countries of European Union introduced euro notes and coin as legal currency and replaced their national currencies by euro using conversion rates. The conversion rates for Belgium, Germany, France, Italy, Netherlands, and Spain are: 40.3399 Belgium Francs, 1.95583 German Marks, 6.55957 French Francs, 1936.27 Italian Lire, 2.20371 Dutch Guilders, and 166.386 Spanish Pesetas for 1 euro. $^{3}$ To express the exchange rate of these six countries for the period 1973:07 to 2001:12 at Euro per US\$, the prevailing exchange rates at national currencies per US\$ are converted by using the conversion rate before using formula (3). Besides, the exchange rate of Pound Sterling (for all period) and Euro (from 2001:12 to 2008:12) were available as units of US\$ per unit of Pound Sterling and Euro. We invert the prevailing rates for Pound sterling and Euro before using formula (3).

Calculation of Bilateral Nominal Exchange Rate Index: Using the bilateral nominal exchange rate calculated in 3.4, the bilateral nominal exchange rate index can be calculated by using formula (4).

$$
N E R I_{t}^{i}=\frac{N E R_{t}^{i}}{N E R_{b}^{i}} * 100 \cdots(4)
$$

where, $N E R I_{t}^{i}=$ NER index of taka with partner i's currency at period t;

$N E R_{t}^{i}=$ units of country i's currency per unit of taka at period t;

$N E R_{b}^{i}=$ units of country i's currency per unit of taka at base period;

Using formula (4), the bilateral nominal exchange rate indices of taka for the period 1973:07-2008:12 are calculated on monthly basis for constructing the bilateral nominal effective exchange rate (NEER) index.

Calculation of Bilateral Real Exchange Rate: Bilateral real exchange rate is calculated by adjusting the bilateral nominal exchange rate with the ratio of CPI. But the consumer price indices for different countries for the period 1973:07 to 2008:12 are not available at a single base period. Therefore, it is necessary to convert the prevailing CPI's into single base (FY01 $=100$ ) before using them in the formula. Now the bilateral real exchange rates are calculated by using formula (5).

$$
R E R_{t}^{i}=N E R_{t}^{i} \frac{C P I_{t}}{C P I_{t}^{i}} \ldots(5)
$$

where, $R E R_{t}^{i}=$ real exchange rate of taka with partner i's currency at period t;

$N E R_{t}^{i}=$ nominal exchange rate of taka with i's currency at period t;

$C P I_{t}=$ consumer price index of Bangladesh at period t;

\footnotetext{
${ }^{3}$ Source: www.euro.gov.uk
} 


$$
C P I_{t}^{i}=\text { consumer price index of partner } \mathrm{i} \text { at period t.; }
$$

The formula is designed in such a way that higher value of RER represents real appreciation and lower value represents real depreciation of domestic currency.

Calculation of Bilateral Real Exchange Rate Index: Bilateral real exchange rate index is calculated by using the following formula:

$$
R E R I_{t}^{i}=\frac{R E R_{t}^{i}}{\operatorname{RER}_{b}^{i}} * 100 \cdots(6)
$$

where, $R E R I_{t}^{i}=$ real exchange rate index of Bangladesh with partner i at period t;

$R E R_{t}^{i}=$ real exchange rate of taka with partner i's currency at period t;

$R E R_{b}^{i}=$ real exchange rate of taka with partner i's currency at base period;

The index is now unit free and ready for use in constructing effective rates. Then the bilateral real exchange rate indices of Bangladesh over 1973:07-2008:12 are calculated for constructing the real effective exchange rate (REER) indices.

From the bilateral indices it is observed that there exists a depreciating trend in the exchange rate of taka against all major partner currency both in nominal and real term except the case of Indonesia. In nominal terms taka appreciated against Indonesian Rupiah over the period under report. In this regard, we draw two graphs for the case of India (the largest trading partner of Bangladesh, see Table 2) and the case of China (the recently added and second largest major trading partner, see Table 2). Graph 1 depicts that taka depreciated against Indian Rupee from the month of July 1973 to July 2007 with some recent trend of appreciation both in nominal and real terms. But the pattern of depreciation is stronger in real term than in nominal term with China (Graph 2).

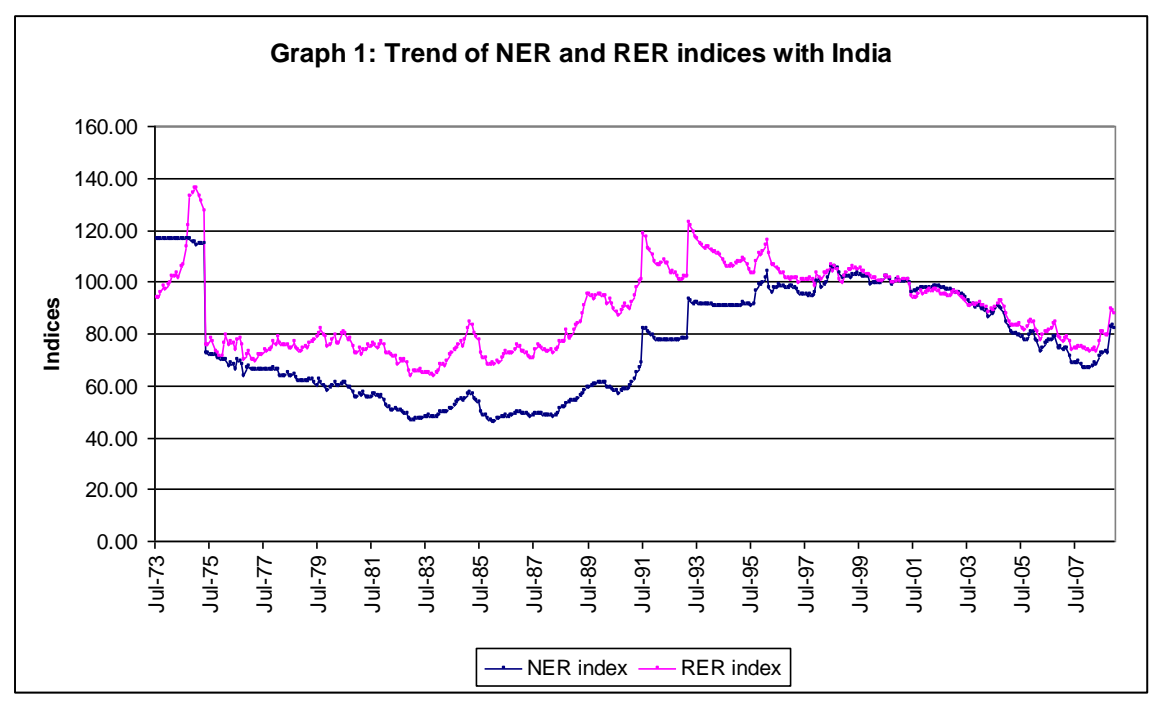




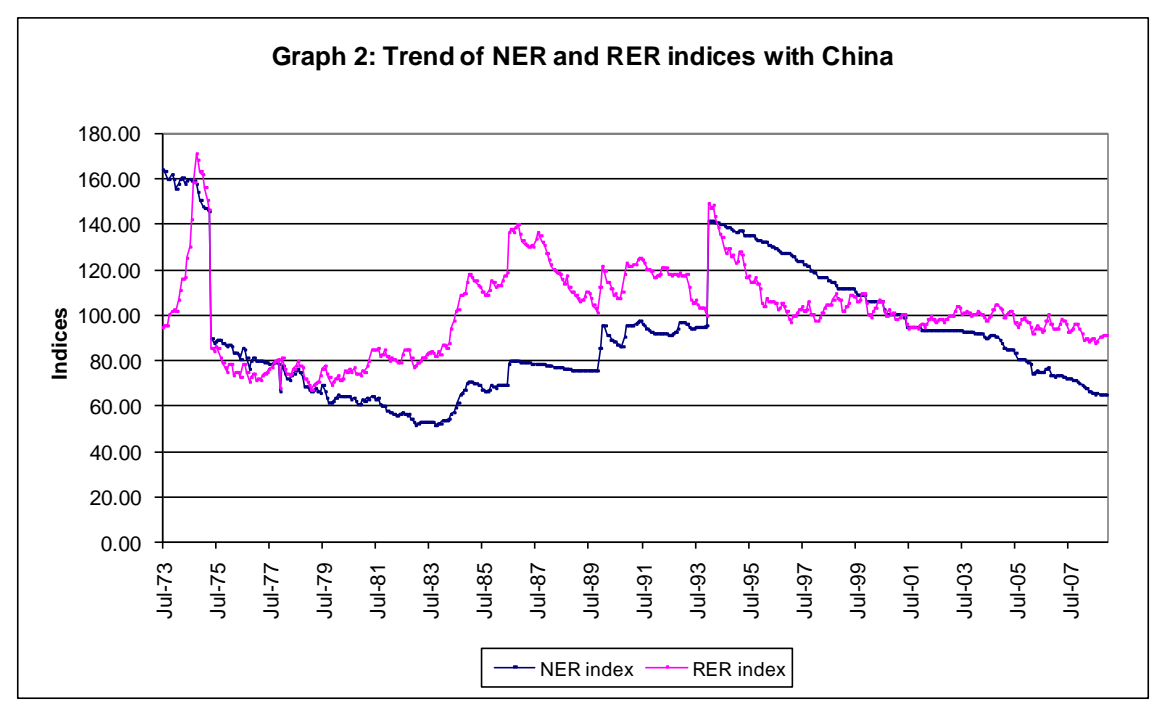

Construction of Effective Exchange Rates: We now construct two different kinds of effective exchange rates namely nominal effective exchange rate (NEER) and real effective exchange rate (REER). Each type of effective exchange rate can be constructed in different ways depending on the calculation of trade weight and the method of averaging. This paper calculates three kinds of trade weights such as the value of exports, the value of imports and the total value of trade separately. ${ }^{4}$ It also uses both the arithmetic and the geometric mean technique for averaging the bilateral exchange rates. ${ }^{5}$

The Nominal Effective Exchange Rate Index: The nominal effective exchange rate index is the weighted average of bilateral nominal exchange rate indices (NERI). Whenever we use arithmetic mean the formula for NEER indices will be as (7) and for geometric mean the formula turns out to be (8).

$$
\begin{aligned}
N_{\text {EERI }} t_{t} & =\sum_{i=1}^{21} W^{i} N E R I_{t}^{i} \cdots(7) \\
N E E R I_{t} & =\prod_{i=1}^{21}\left(N E R I_{t}^{i}\right)^{w^{i}} \ldots(8)
\end{aligned}
$$

where, ${ }_{N E E R I_{t}}=$ nominal effective exchange rate index of Bangladesh at period t, ${ }_{N E R I_{t}^{i}}=$ bilateral nominal exchange rate index of Bangladesh with partner $i$ at period $t$ and $W^{i}=$ trade weight of Bangladesh with partner i. There are six different ways in measuring the trade weights depending on (i) the uses of fixed and variable weights and (ii) the uses of exports weights, imports weights and total trade weights. Using both arithmetic and geometric mean technique for averaging we are able to construct twelve types of NEER indices. Similarly, we are also able to construct twelve types of real effective exchange rate (REER) indices of Bangladesh by using formula (9) and (10) for arithmetic and geometric mean.

$$
\begin{aligned}
\text { REERI }_{t} & =\sum_{i=1}^{21} W^{i} \text { RERI }_{t}^{i} \\
\text { REERI }_{t} & =\prod_{i=1}^{21}\left(\text { RERI }_{t}^{i}\right)^{w^{i}}
\end{aligned}
$$

where, $R E E R I_{t}=$ real effective exchange rate index of Bangladesh at period $\mathrm{t}, \operatorname{RERI}_{t}^{i}=$ bilateral real exchange rate index of Bangladesh with partner $i$ at period $t$.

Construction of Nominal and Real Effective Exchange Rate Indices for Bangladesh: Using the above formulae, we have calculated twenty four types of effective exchange rates of Bangladesh for the period 1973:07-2008:12. But for brevity, we have calculated only six types of effective exchange rate series three for NEER index (NX, NM, and NT) and another three for REER index (RX, RM, and RT) calculated under fixed trade (export plus import) weight using arithmetic mean. Besides, we also calculated the series of nominal exchange rate of taka against US\$, consumer price index of Bangladesh (CPIB), and weighted average (using arithmetic mean and fixed trade weight) of CPI of twenty one partner countries. The

\footnotetext{
${ }^{4}$ NEER and REER indices are presented based on all the three different weights on a fixed weight basis. However, we also calculate the same indices based on variable weights to check the robustness of our result.

${ }^{5}$ We present data based on arithmetic mean only. However, we also use geometric mean to check the robustness of our result.
} 
purchasing power parity index is also calculated. The important series, trade policy bias, is also calculated. The TPB is calculated by dividing the REER index under fixed import weight (RM) by the REER index calculated under fixed export weight (RX). The index of trade policy bias indicates that our export bias has been improving gradually but the progress has been slowed down recently.

Features of Nominal and Real Effective Exchange Rates in Bangladesh: The striking features of the series of the nominal and the real effective exchange rate indices are as follows:

- There is a declining trend for all the effective exchange rate indices of Bangladesh which indicates the overall depreciation of taka against partner currency both in nominal and the real term.
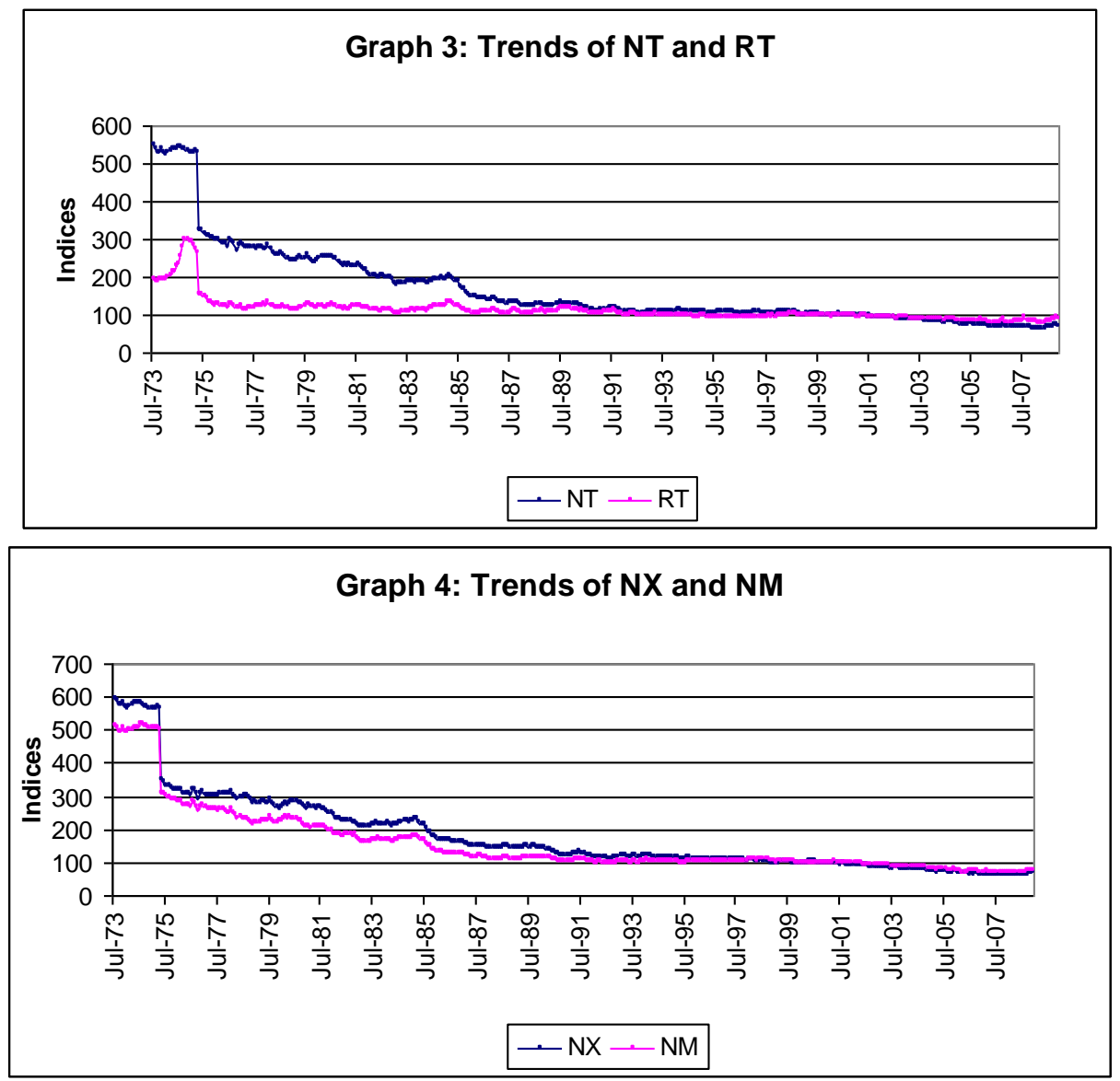

- From graph 3, it is observed that the value of NEER indices (NT) was higher than the REER indices (RT) during the long period up to FY99. This implies that the inflation rate of Bangladesh was lower than the partner countries at the earlier stage but it is becoming continuously higher than the partner countries after FY99.

- Graph 4 shows the trend of NEER indices constructed under fixed export weight (NM) and fixed import weight (NM). It is observed that the NEER indices constructed under export weight is higher than the NEER indices constructed under import weight up to July 1995. After this period the two lines coincide with each other. 


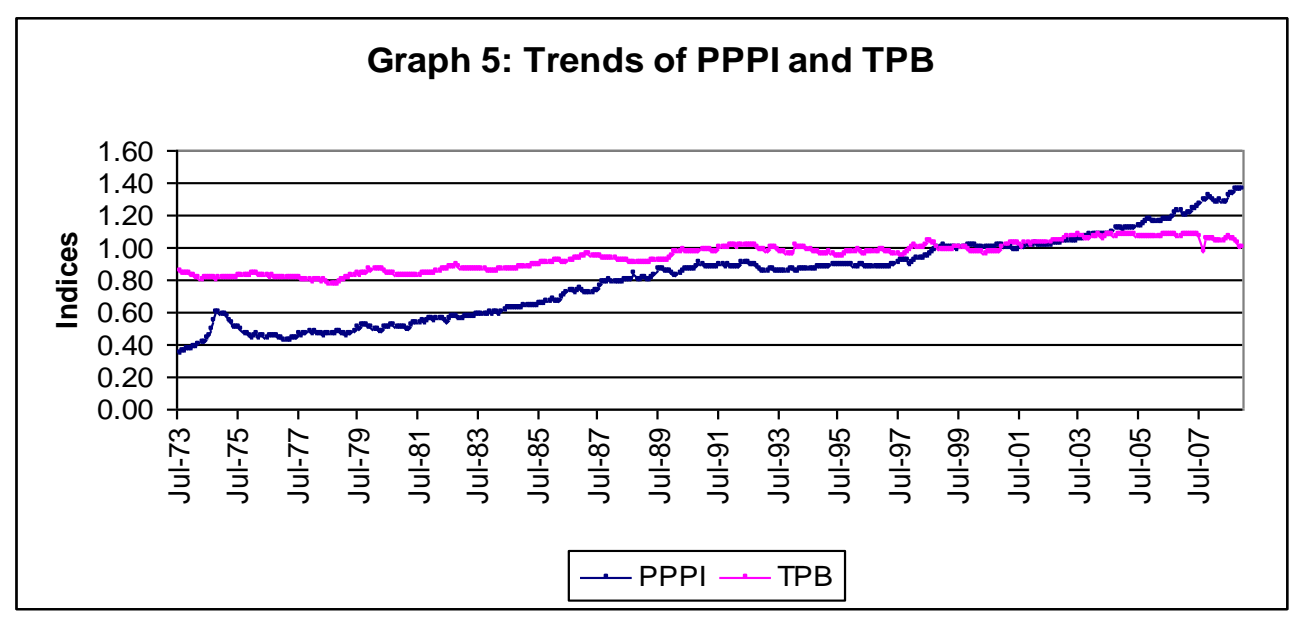

- Graph 5 depicts the trend of purchasing power parity index (PPPI) and trade policy or anti export bias (TPB) index. The TPB line indicates that the trade policy of Bangladesh is going in favor of export after December 2000. However the process has recently been slowed down. The monotonically increasing trend of PPPI in graph 5 indicates the upward trend of inflation in Bangladesh compared to her major trading partners.

The findings are striking in the sense that neither Rahman (1992) nor other studies conducted on other countries like Bahmani-Oskooee (1995, 2001); Bahmani-Oskooee and Mirzai (2000); Bahmani-Oskooee and Gelan (2007); Bahmani-Oskooee and Harvey (2007); Bahmani-Oskooee and Kandil (2007) covers all the aspects of weighting, averaging and other issues at a time.

\section{Concluding Remarks}

The concept of nominal and effective exchange rates is extremely useful for examining the overall competitiveness and debt-service liability of a country vis-à-vis her major trading partners. In the context of aggregate export, import or trade balance modeling especially in the 80s these concepts received considerable importance to policymakers and researchers. Following this path, IMF started preparing its data base of effective exchange rates for developed countries and data is available in its database named International Financial Statistics. However, there is a growing demand for constructing the effective exchange rates for developing countries. To fill this gap, economists made attempts to construct effective exchange rates for several developing countries (Bahmani-Oskooee 1995; Bahmani-Oskooee and Mirzai 2000; Bahmani-Oskooee 2001; Bahmani-Oskooee and Gelan 2007; Bahmani-Oskooee and Kandil 2007; Bahmani-Oskooee and Harvey 2007).

Unfortunately, in the category of developing countries Bangladesh has not been included even though she is making noticeable progress in the international arena in recent days. Bangladesh Bank pioneered in constructing this kind of indices by using eight currencies which captures only 60 percent her total trade. The data prepared by Bangladesh Bank covers only the time period ranging from 1986 onwards by using different base periods for which the data are not comparable. BB uses only total trade weights to construct the index. Hence, we felt the need for conducting a comprehensive study by using a single base period, more data points, using trade weights, export weights, and import weights at a time, using both the fixed and the variable weights, and using both the geometric mean and the arithmetic mean etc. in a systematic fashion.

The trading partners used in this study capture about 80 percent trade of Bangladesh. From the study it is observed that there is a declining trend in the effective exchange rates of Bangladesh which indicates that Bangladeshi Taka depreciated both in nominal and real terms over the period from 1973 to 2008. However, the anti-export bias index or trade policy bias index indicates that our export is becoming more and more competitive gradually starting from December 2000 but the progress has recently been slowed down. This broad data base may be extended further by incorporating more data points of year 2009 which may provide a guideline for examining the competitiveness of Bangladesh more closely. 


\section{References}

Bahmani-Oskooee, M. (1995). Real and nominal effective exchange Rates for 22 LDCs: 1971I-1990IV. Applied Economics, 27(7), 591-604.

Bahmani-Oskooee, M. (2001). Nominal and real effective exchange rates of Middle Eastern countries and their trade performance. Applied Economics, 33(1), 103-111.

Bahmani-Oskooee, M. \& Gelan, A. (2007), Real and nominal effective exchange rates for African countries: 1971: I-2004: III. Applied Economics, 39, 961-979.

Bahmani-Oskooee, M. \& Goswami, G. G. (2003). A disaggregated approach to test the J-curve phenomenon: Japan vs. her major trading partners. Journal of Economics and finance, 27: 102113.

Bahmani-Oskooee, M. \& Harvey, H. (2007). Real and nominal exchange rates for LDCs: 1971I-2004IV. International Trade Journal, 21(4), 385-416.

Bahmani-Oskooee, M. \& Kandil, M. (2007). Real and nominal effective exchange rate I MENA countries: 1970-2004. Applied Economics, 39(19), 2489-2501.

Bahmani-Oskooee, M. \& Mirzai, A. (2000). Real and nominal effective exchange rates for developing countries: 1973:1-1997:3. Applied Economics, 32(4), 411-428.

Rahman, S. H. (1992). Structural adjustment and macroeconomic performance in Bangladesh in the 1980s. The Bangladesh Development Studies, 20(2\&3), 89-125. 


\section{Appendix A:}

Note: NER : Nominal Exchange Rate (Units of taka per US\$);

CPIB : Consumer price index of Bangladesh;

FCPI : Weighted average CPI of partner countries for fixed trade Weights;

PPPI : Purchasing Power Parity Index (CPIB/FCPI);

NT : NEER index based on total trade weight;

NX : NEER index based on export weight;

NM : NEER index based on import weight;

RT : REER index based on total trade weight;

RX : REER index based on export weight;

RM : REER index based on import weight;

TPB : Index of trade policy bias or anti export bias (RM/RX).

\section{Appendix B: Sources of Data}

(a) International Financial Statistics, IMF (Various Issues): The monthly data on 'Bilateral Nominal Exchange Rates' and 'Consumer Price Indices' are collected from both the paper and electronic version (CD-ROM) of this source;

(b) Direction of Trade Statistics, IMF (Various Issues): The monthly data of country-wise exports and imports of Bangladesh are collected from the electronic version of this source;

(c) Monthly Economic Trends, Bangladesh Bank (Various Issues): The monthly data especially on 'Exchange Rate of Taka against US\$' and 'Consumer Price Index of Bangladesh' are collected from this source;

(d) Annual Export Receipts 2007-2008, Bangladesh Bank: The data of country-wise export receipts for FY01 are collected from this source;

(e) Annual Import Payments 2007-2008, Bangladesh Bank: The data of country-wise import payments for FY01 are collected from this source;

(f) Statistics Department, Bangladesh Bank: Some updated data regarding country-wise exports and imports of Bangladesh are collected from this source. 